University of Michigan Law School

University of Michigan Law School Scholarship Repository

\title{
Small Change, Big Consequences - Partial Medicaid Expansions under the ACA
}

\author{
Adrianna Mclntyre \\ Harvard University \\ Allan M. Joseph \\ Brown University \\ Nicholas Bagley \\ University of Michigan Law School, nbagley@umich.edu
}

Available at: https://repository.law.umich.edu/articles/2002

Follow this and additional works at: https://repository.law.umich.edu/articles

Part of the Health Law and Policy Commons, Insurance Law Commons, Legislation Commons, and the State and Local Government Law Commons

\section{Recommended Citation}

Bagley, Nicholas. "Small Change, Big Consequences - Partial Medicaid Expansions under the ACA." Adrianna McIntyre and Allan M. Joseph, co-authors. New Eng. J. Med. 377, no. 11 (2017): 1004-6.

This Article is brought to you for free and open access by the Faculty Scholarship at University of Michigan Law School Scholarship Repository. It has been accepted for inclusion in Articles by an authorized administrator of University of Michigan Law School Scholarship Repository. For more information, please contact mlaw.repository@umich.edu. 


\section{Small Change, Big Consequences - Partial Medicaid Expansions under the ACA}

Adrianna McIntyre, M.P.P., M.P.H., Allan M. Joseph, M.P.H., and Nicholas Bagley, J.D.

Though congressional efforts to repeal and replace the Affordable Care Act (ACA) seem to have stalled, the Trump administration retains broad executive authority to reshape the health care landscape. Perhaps the most consequential choices that the administration will make pertain to Medicaid, which today covers more than 1 in 5 Americans. ${ }^{1}$

Much has been made of proposals to introduce work requirements or cost sharing to the program. But another decision of arguably greater long-term significance has been overlooked: whether to allow "partial expansions" pursuant to a state Medicaid waiver. Arkansas has already submitted a waiver request for a partial expansion, and other states may well follow its lead. ${ }^{2}$

To understand Arkansas's request, and why it matters so much, some background is in order. Medicaid waivers have long allowed states to experiment with delivery reform and coverage expansions, but waivers became more consequential in 2012, when the U.S. Supreme Court gave states a choice about whether to expand their Medicaid programs to cover everyone with an income of up to $138 \%$ of the federal poverty level. Some states sought greater flexibility to expand Medicaid on their own terms, which made participation in the expansion more palatable in Republicancontrolled states. After intense negotiations, the Obama administration granted expansion waivers to seven states.
In general, Obama-era expansion waivers permitted adoption of rules congenial to Republican policymakers. Indiana, for example, used its waiver to impose modest premiums and cost sharing on some beneficiaries and to adopt incentives for healthy behavior. Notably, Seema Verma, the current administrator of the Centers for Medicare and Medicaid Services (CMS), oversaw the Indiana waiver's design and implementation.

These waivers, however, did not grant red states everything they requested. The Obama administration refused to approve waivers that would have conditioned Medicaid eligibility for some beneficiaries on their ability to find work. It denied waivers that would have terminated coverage for beneficiaries with incomes below the poverty level if they failed to make out-of-pocket payments for medical care. And it declined states' requests to partially expand their Medicaid programs to enroll beneficiaries with incomes up to $100 \%$ of the poverty level, but not those between $100 \%$ and $138 \%$.

Why were states interested in these partial expansions? Starting in 2020, states are responsible for covering $10 \%$ of the costs associated with the Medicaid expansion. Because of a drafting mistake, however, the ACA says that the 100-to-138 population can receive subsidies to purchase a private health plan on the exchanges - but only if they are ineligible for Medicaid. ${ }^{3}$ For those people, the federal government bears the entire cost of subsidizing private coverage, with no contribution from the states. As a result, the states save money for every beneficiary whom they can move from Medicaid into their exchanges.

The Obama administration justified its denials by noting that the ACA "does not provide for a phased-in or partial expansion." ${ }^{4}$ As a legal argument, this position left much to be desired. It's true that the ACA does not explicitly contemplate partial expansions. What it does, instead, is amend the section of the Medicaid statute governing eligibility (42 U.S.C. \$1396a) to make everyone with incomes of up to $138 \%$ of the poverty level eligible for Medicaid.

Yet the ACA kept in place the part of the Medicaid statute giving CMS broad authority to "waive compliance with any of the requirements of section . . . 1396a." The waiver must be "likely to assist in promoting the objectives" of the Medicaid program, but that's an elastic legal standard, and courts are likely to defer if CMS concludes that shifting Medicaid beneficiaries to private coverage will give them better access to their preferred physicians and hospitals. Preexisting waiver authority thus appears to allow states to tinker with the ACA's eligibility rules.

Now that repeal of the ACA's Medicaid expansion seems unlikely, will the Trump administration allow partial expansions? Arkansas's waiver request will force an 
answer to that question. Because Arkansas is already operating under a unique waiver that allows it to enroll Medicaid beneficiaries in exchange plans, partial expansion would have relatively muted effects in the state: it would just rejigger state-federal financing arrangements. Nonetheless, acceding to Arkansas's request would set a precedent with extraordinary practical, budgetary, and political consequences.

On the practical side, many states would probably demand similar waivers. Unlike the federal government, states are obliged under their constitutions to balance their budgets every year. They will welcome the chance to reduce Medicaid obligations and alleviate budgetary strain. Hospitals, physicians, and other providers will probably support partial expansion because private insurers pay them better than Medicaid does.

Partial expansion would not just shift a financial burden to the federal government; it could also increase the size of that burden. Arkansas's decision to enroll beneficiaries in private plans increased expansion costs by $24 \%$; in other states, the disparity between Medicaid and private costs could be much higher. Between premium subsidies and supplemental cost-sharing reductions, the federal government will probably shoulder more than $90 \%$ of the price tag for this costlier coverage, with beneficiaries picking up the difference.

Partial expansion could also degrade the quality of states' individual insurance markets. One analysis found that exchange premiums were $7 \%$ higher in nonexpansion states - where the population with incomes between
$100 \%$ and $138 \%$ of the poverty level already qualifies for subsidized coverage - than in expansion states, after adjustment for state differences. Though other factors may contribute to this finding, one possible explanation is that the 100 -to-138 population is sicker than the rest of the individual-market risk pool. If so, adding them to the exchanges will drive premiums up for everyone. Federal subsidies for current enrollees would have to increase to keep pace, on top of the spending hike associated with moving Medicaid beneficiaries into private coverage.

In addition, the 100-to-138 population may not welcome be- plans, increasing the proportion of the population that is uninsured.

Private coverage could offer some advantages over Medicaid. Providers tend to be more likely to accept private coverage than Medicaid, which suggests that marketplace enrollees may have access to a wider range of physicians and hospitals. The data indicate, however, that access problems for Medicaid beneficiaries are less acute than is commonly assumed. ${ }^{5}$ And any improvement in access must be weighed against the substantial costs of moving the 100 -to-138 population to private coverage.

Partial expansion may yield another benefit: it could encourage

\section{Now that repeal of the ACA's Medicaid expansion seems unlikely, will the Trump administration allow partial expansions? Arkansas's waiver request will force an answer to that question.}

ing moved out of Medicaid. Outof-pocket payments in Medicaid are nominal, if they're imposed at all. Matters are different in the private market, where high deductibles have become the norm. Cost-sharing reductions under the ACA shield beneficiaries from extreme health care expenses, but even enrollees with the most generous cost-sharing reductions still face an average annual deductible of about $\$ 250$. Deductibles can be as high as $\$ 850$ in some plans, and total out-of-pocket spending limits can hit $\$ 2,350-$ far out of reach for people on the edge of poverty. As a result, some current Medicaid enrollees will decline to enroll in exchange holdout states to expand their Medicaid programs to everyone with incomes up to $100 \%$ of the poverty level. Some of those states might have expanded eventually, but allowing for partial expansions could accelerate the timeline. Whether moving more states into the "yes" column justifies the costs of partial expansion, however, is an open question.

In short, the stakes are high in the coming debate over partial Medicaid expansions, with farreaching consequences for patients, state governments, and the federal budget. It's not yet clear what position the Trump administration will take, but it should be cautious. If CMS grants a 
waiver to one state, it will have little choice but to grant waivers

to any other states that request them. The damage to Medicaid beneficiaries,

Fith An audio interview is available at NEJM.org

the exchange population, and the federal budget could be serious.

Disclosure forms provided by the authors are available at NEJM.org.

From Harvard University, Cambridge (A.M.), and the Harvard T.H. Chan School of Public Health, Boston (A.M.J.) — both in Massachusetts; the Warren Alpert Medical School,
Brown University, Providence, RI (A.M.J.); and the University of Michigan Law Schoo and the Institute for Healthcare Policy and Innovation, University of Michigan — both in Ann Arbor (N.B.).

This article was published on August 9, 2017, at NEJM.org.

1. Keehan SP, Stone DA, Poisal JA, et al National health expenditure projections, 2016-25: price increases, aging push sector to 20 percent of economy. Health Aff (Millwood) 2017;36:553-63.

2. Arkansas works amendment. Medicaid .gov. July 11, 2017 (https:/public.medicaid.gov/ connect.ti/public.comments/view?objectId= 1891331).
3. Scott $\mathrm{D}$. The story behind the biggest mistake in Obamacare. Governing. February 19, 2013 (http://www.governing.com/blogs/ fedwatch/gov-obamacare-mistake.html).

4. Centers for Medicare \& Medicaid Services. Frequently asked questions on exchanges, market reforms and Medicaid. December 10, 2012 (https://www.cms.gov/CCIIO/Resources/ Files/Downloads/exchanges-faqs-12-10-2012 .pdf).

5. Sommers BD, Blendon RJ, Orav EJ. Both the 'private option' and traditional Medicaid expansions improved access to care for lowincome adults. Health Aff (Millwood) 2016; 35:96-105.

DOI: 10.1056/NEJMp1710265

Copyright (c) 2017 Massachusetts Medical Society. 